Article

\title{
Enhanced Conductivity of Composite Membranes Based on Sulfonated Poly(Ether Ether Ketone) (SPEEK) with Zeolitic Imidazolate Frameworks (ZIFs)
}

\author{
Arturo Barjola ${ }^{1}$, Jorge Escorihuela ${ }^{1}\left(\mathbb{0}\right.$, Andreu Andrio ${ }^{2}{ }^{\circledR}$, Enrique Giménez $^{3}$ and \\ Vicente Compañ ${ }^{1, * \mathbb{D}}$ \\ 1 Escuela Técnica Superior de Ingenieros Industriales, Departamento de Termodinámica Aplicada, Universitat \\ Politècnica de València, Camino de Vera s/n, 46020 Valencia, Spain; arbarrui@doctor.upv.es (A.B.); \\ escorihu@uji.es (J.E.) \\ 2 Departamento de Física Aplicada, Universitat Jaume I, Avda. Sos Baynat, s/n, 12080, Castelló de la Plana, \\ Spain; andrio@uji.es \\ 3 Instituto de Tecnología de Materiales, Universitat Politècnica de València, Camino de Vera s/n, 46020 \\ Valencia, Spain; enrique.gimenez@mcm.upv.es \\ * Correspondence: vicommo@ter.upv.es; Tel.: +34-96-387-9328
}

Received: 23 November 2018; Accepted: 7 December 2018; Published: 13 December 2018

\begin{abstract}
The zeolitic imidazolate frameworks (ZIFs) ZIF-8, ZIF-67, and a Zn/Co bimetallic mixture (ZMix) were synthesized and used as fillers in the preparation of composite sulfonated poly(ether ether ketone) (SPEEK) membranes. The presence of the ZIFs in the polymeric matrix enhanced proton transport relative to that observed for SPEEK or ZIFs alone. The real and imaginary parts of the complex conductivity were obtained by electrochemical impedance spectroscopy (EIS), and the temperature and frequency dependence of the real part of the conductivity were analyzed. The results at different temperatures show that the direct current (dc) conductivity was three orders of magnitude higher for composite membranes than for SPEEK, and that of the SPEEK/ZMix membrane was higher than those for SPEEK/Z8 and SPEEK/Z67, respectively. This behavior turns out to be more evident as the temperature increases: the conductivity of the SPEEK/ZMix was $8.5 \times 10^{-3}$ $\mathrm{S} \cdot \mathrm{cm}^{-1}$, while for the SPEEK/Z8 and SPEEK/Z67 membranes, the values were $2.5 \times 10^{-3} \mathrm{~S} \cdot \mathrm{cm}^{-1}$ and $1.6 \times 10^{-3} \mathrm{~S} \cdot \mathrm{cm}^{-1}$, respectively, at $120^{\circ} \mathrm{C}$. Similarly, the real and imaginary parts of the complex dielectric constant were obtained, and an analysis of $\tan \delta$ was carried out for all of the membranes under study. Using this value, the diffusion coefficient and the charge carrier density were obtained using the analysis of electrode polarization (EP).
\end{abstract}

Keywords: proton exchange membrane; sulfonated poly(ether ether ketone); zeolitic imidazoleate framework; proton conduction

\section{Introduction}

The current environmental problems generated by the use of fossil fuels along the last century has driven the scientific community attention toward the search for more sustainable energy systems. In this regard, hydrogen appears as a potential alternative to traditional fuels; its use in fuel cells, which are electrochemical devices that are capable of transforming chemical energy into electrical energy, has significantly increased in the past decade $[1,2]$. In a typical proton exchange membrane fuel cell (PEMFC), the polymeric electrolyte membrane is the fundamental component of the electrochemical device $[3,4]$. According to its range of operating temperature, PEMFCs can be classified into three main categories: (a) low-temperature PEMFCs (LT-PEMFCs), which operate around $60-80{ }^{\circ} \mathrm{C}$ [5]; (b) intermediate temperature (IT-PEMFCs), with an operating temperature in the $80-140{ }^{\circ} \mathrm{C}$ range [6], and 
(c) high temperature (HT-PEMFCs), which operate above $140{ }^{\circ} \mathrm{C}$ up to $220^{\circ} \mathrm{C}[7,8]$. Among the different variety of electrolyte membranes [9], those based on perfluorosulfonic acid (PFSA) polymers, such as Nafion ${ }^{\circledR}$, have been efficiently used as LT-PEMFCs, due to their excellent chemical and mechanical stability and high conductivity (values higher than $0.1 \mathrm{~S} / \mathrm{cm}$ ) at temperatures around $80{ }^{\circ} \mathrm{C}$ and high relative humidity conditions [10]. The main problems associated with the use of Nafion-based membranes are their high cost and the loss of conductivity performance at temperatures higher than $80^{\circ} \mathrm{C}$ [11]. In this regard, IT-PEMFCs have emerged as an alternative to Nafion for their application to automobiles, as operating at this temperature allows an improved stability and durability due to the presence of less liquid water inside the membrane [12], the reduction of catalyst poisoning by CO on the fuel cell anode [13], and increases in the oxidation of electrode kinetics [14]. Among the various types of IT-PEMFC membranes, those based on sulfonated poly(ether ether ketone) (SPEEK) have been widely studied due to due to its simple preparation procedures and low cost, good thermal and mechanical stability, good proton conductivity, and fuel barrier properties $[15,16]$.

Poly(ether ether ketone) (PEEK) is a linear polymer with an aromatic backbone, in which 1,4-disubstituted phenyl groups are separated by ether $\left(-\mathrm{O}_{-}\right)$and carbonyl $(-\mathrm{C}=\mathrm{O}-)$ linkages (Figure 1) [17]. This polymer is insoluble in organic solvents, which is a serious drawback for several applications, including membrane preparation. However, when sulfonated, PEEK loses its crystallinity and becomes soluble in a wide range of organic solvents depending on the degree of sulfonation (DS) [18]. Membranes based on SPEEK have a conductivity close to Nafion [19] and a Tg of around to $180{ }^{\circ} \mathrm{C}$, making them candidates to be used above $100{ }^{\circ} \mathrm{C}$, which would substantially improve the efficiency of the system. Different approaches have been developed in order to improve the proton conductivity of SPEEK membranes. One of them is based in developing mixed-matrix membranes (MMMs), which are composite membranes made by combining an inorganic-organic hybrid material and a polymer matrix [20]. Many fillers have been used such as graphene [21], carbon nanotubes and nanohorns [22,23], silica [24], zeolites [25], metallacarboranes [26], etc. In recent years, the use of metal organic frameworks (MOFs) as fillers in polymeric electrolyte membranes has attracted a growing interest due to their high conductivity, which is mainly attributed to their high porosity [27-29].

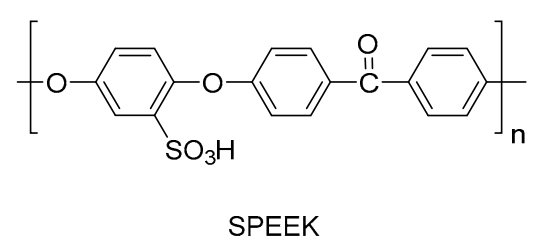

SPEEK

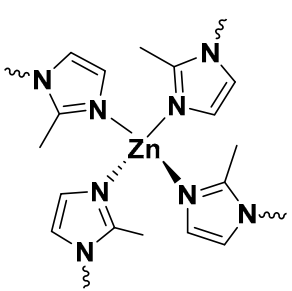

ZIF-8

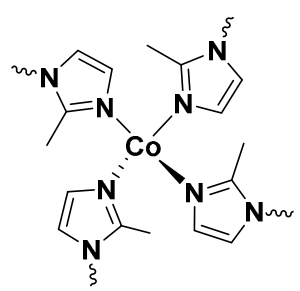

ZIF-67

Figure 1. Chemical structure of sulfonated poly(ether-ether-ketone) (SPEEK) polymer repeating unit and zeolitic imidazolate framework (ZIF)-8 and ZIF-67.

MOFs are a subclass of coordination polymers consisting of transition metal ions coordinated to multidentate organic ligands to form three-dimensional crystalline structures [30,31]. MOFs have shown to be promising materials for various applications such as gas storage [32], gas separation [33], heterogeneous catalysis [34,35], chemical sensors [36,37], biomedicine [38], and drug delivery [39,40]. The incorporation of MOFs into polymeric SPEEK membranes has shown a significant improvement of the performance in fuel cell applications [41-43]. Among the reported MOF-containing PEMs, proton conductivities of $268 \mathrm{mS} \cdot \mathrm{cm}^{-1}$ and $306 \mathrm{mS} \cdot \mathrm{cm}^{-1}$ have been reported for SPEEK membranes containing sulfonated UiO-66 and MIL-101, respectively with under 100\% relative humidity (RH) conditions and temperatures below $70{ }^{\circ} \mathrm{C}$. However, these values decrease at temperatures higher than $100{ }^{\circ} \mathrm{C}$ in anhydrous or low-humidity conditions. One family of MOFs are zeolitic imidazolate frameworks (ZIFs), which are neutral porous framework structures with high chemical and thermal stability based on imidazolate rings coordinated to a tetrahedral divalent metal cation (Figure 1) [44,45]. The use 
of this subclass of MOFs has also been demonstrated in the preparation of PEMs, reaching proton conductivities up to $24 \mathrm{mS} \cdot \mathrm{cm}^{-1}$, and $50 \mathrm{mS} \cdot \mathrm{cm}^{-1}$ at $120^{\circ} \mathrm{C}$ and $30 \% \mathrm{RH}$ for SPEEK membranes with ZIF-8 and ZIF-8/CNT hybrid cross-linked networks, respectively [46].

Herein, we report on the preparation and characterization of proton conductivity of composite SPEEK membranes containing ZIF particles into the polymeric matrix. ZIF-8, ZIF-67, and a Zn/Co bimetallic mixture (1:1 w:w) were as synthesized, and used as fillers in SPEEK mixed-matrix membranes. Proton conduction measurements showed that these composite membranes can reach conductivities of up to $30 \mathrm{mS} \cdot \mathrm{cm}^{-1}$ at $120^{\circ} \mathrm{C}$, which make them suitable for its application in IT-PEMFCs. A deep study of the conductivity allowed us to obtain the real and imaginary parts of the complex dielectric constant, and an analysis of $\tan \delta$ was carried out for all of the membranes under study. Using this value, the diffusion coefficient and the charge carrier density were obtained using the analysis of electrode polarization (EP).

\section{Materials and Methods}

\subsection{Materials}

Granulated SPEEK (FUMION E ionomers) with an ion-exchange capacity (IEC) of $1.75 \mathrm{mmol} / \mathrm{g}$ were acquired from Fumatech $\mathrm{GmbH}$ (St. Ingbert, Germany). N,N-Dimethylacetamide (DMAc) 99.8\% solvent, methanol, 2-methylimidazole (2-MIm, 99\%), zinc chloride ( $\left.\mathrm{ZnCl}_{2}, \geq 97 \%\right)$, cobalt chloride $\left(\mathrm{CoCl}_{2}, \geq 99.8 \%\right)$ and sodium formate $\left(\mathrm{HCO}_{2} \mathrm{Na}, \geq 99 \%\right)$ were purchased from Sigma-Aldrich (Sigma-Aldrich Química SL, Madrid, Spain).

\subsection{Experimental Procedures}

\subsubsection{Synthesis of ZIF-8}

ZIF-8 was synthesized according to the reported procedure [47]. In brief, $0.82 \mathrm{~g}$ (10 mmol) of 2-MIm and $0.76 \mathrm{~g} \mathrm{(11} \mathrm{mmol)} \mathrm{of} \mathrm{sodium} \mathrm{formate} \mathrm{were} \mathrm{dissolved} \mathrm{in} 30 \mathrm{~mL}$ of methanol and, then mixed with a $0.26-\mathrm{M} \mathrm{ZnCl}_{2}$ methanolic solution. The obtained product was washed, centrifuged, and dried under vacuum at $80^{\circ} \mathrm{C}$ for $12 \mathrm{~h}$.

\subsubsection{Synthesis of ZIF-67}

Z67 was synthesized following a similar procedure as described for ZIF-8. Briefly, $0.82 \mathrm{~g}$ (10 mmol) of 2-MIm and $0.76 \mathrm{~g}$ (11 mmol) of sodium formate were dissolved in $30 \mathrm{~mL}$ of methanol and then mixed with a $0.26-\mathrm{M} \mathrm{CoCl}_{2}$ methanolic solution. The obtained product was washed, centrifuged, and dried under vacuum at $80^{\circ} \mathrm{C}$ for $12 \mathrm{~h}$.

\subsubsection{Membrane Preparation}

SPEEK was dried at $100{ }^{\circ} \mathrm{C}$ for $24 \mathrm{~h}$ in vacuum atmosphere and stored in a sealed container to avoid water absorption before the preparation of membranes. A SPEEK polymer with an IEC value of around $1.75 \mathrm{meq} \cdot \mathrm{g}^{-1}(10 \mathrm{wt}$ \% $\%$ was dissolved in DMAc, cast on a Petri dish, and the solvent was evaporated at $80^{\circ} \mathrm{C}$ overnight followed by a treatment at $140{ }^{\circ} \mathrm{C}$ for two hours (Figure 2). Membranes with a thickness of about $150 \mu \mathrm{m}$ were obtained. 


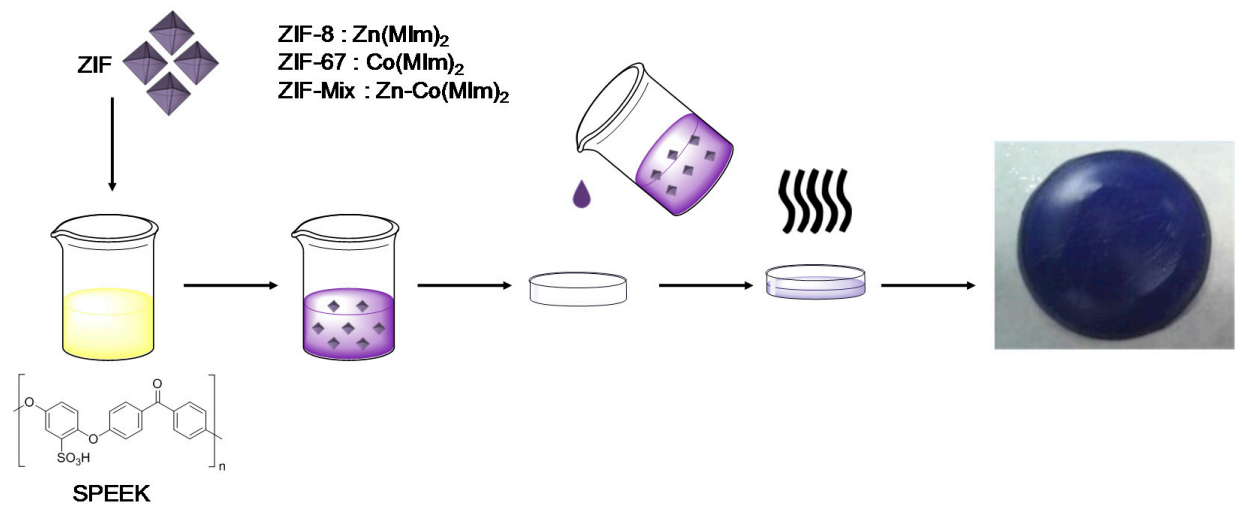

Figure 2. Schematic representation of casting method for membrane preparation.

\subsection{Characterization}

Powder X-ray diffraction (XRD) was acquired using a D/Max-2500PC diffractometer (Rigaku Europe SE, Neu-Isenburg, Germany) with Cu K radiation $(\lambda=1.5406 \AA)$ in the $2 \theta$ range between $10-50$, and a scanning rate and step size of $0.02 \mathrm{~min}^{-1}$, respectively. Thermogravimetric analysis (TGA) was performed on a thermogravimetric analyzer TGA Q50 (Waters Cromatografia, S.A., Division TA Instruments, Cerdanyola del Valles, Spain). Samples (5-10 mg) were weighed in zirconia crucibles and heated under nitrogen atmosphere from $25^{\circ} \mathrm{C}$ to $800{ }^{\circ} \mathrm{C}$ at a heating rate of $10^{\circ} \mathrm{C} \cdot \mathrm{min}^{-1}$. For surface area and porosity analysis, the solid or membrane was dried in a vacuum oven at $100{ }^{\circ} \mathrm{C}$ for five hours, and activated at $100{ }^{\circ} \mathrm{C}$ for 12 hours on a SmartVacPrep instrument (Micromeritics Instrument Corporation, Norcross, GA, USA). All of the $\mathrm{N}_{2}$ isotherms were measured on a Micromeritics Tristar II (Micromeritics, Norcross, GA, USA) at room temperature. Consistency criteria were adapted to choose the pressure range selection for Brunauer-Emmett-Teller (BET) calculation. The tensile tests from each thin-film composite membrane were performed using a Shimadzu AGS-X Universal Testing Machine (Izasa Scientific, Madrid, Spain). The mechanical parameters were determined from average of five samples. For all of the tests, a tensile speed of five $\mathrm{mm} \cdot \mathrm{min}^{-1}$ and a load cell of $500 \mathrm{~N}$ was used. Proton conductivity measurements of the membranes in the transversal direction were performed in the temperature range between $20-120^{\circ} \mathrm{C}$ by electrochemical impedance spectroscopy (EIS) in the frequency interval of $10^{-1}<\mathrm{f}<10^{7} \mathrm{~Hz}$, applying a $0.1-\mathrm{V}$ signal amplitude. A Novocontrol broadband dielectric spectrometer (Novocontrol Technologies, Hundsangen, Germany) integrated with an SR 830 lock-in amplifier with an Alpha dielectric interface was used.

Samples were initially dried under vacuum at $100{ }^{\circ} \mathrm{C}$ for $24 \mathrm{~h}$. Next, $1.5 \times 1.5 \mathrm{~cm}$ membranes were immersed in deionized water at room temperature for two days, and then wiped with absorbent paper to remove the surface water.

Water uptake was calculated from the difference between the wet and dry weight of the membranes, according to the following expression:

$$
\text { Water Uptake }(\%)=\frac{\mathrm{w}_{\text {wet }}-\mathrm{w}_{\mathrm{dry}}}{\mathrm{w}_{\mathrm{dry}}} \times 100
$$

where $\mathrm{w}_{\text {wet }}$ and $\mathrm{w}_{\text {dry }}$ refer to the membrane's weight after its immersion in deionized water for at least $48 \mathrm{~h}$ at room temperature, and the membrane's weight after drying at $120{ }^{\circ} \mathrm{C}$ for at least $24 \mathrm{~h}$, respectively.

The swelling degree was measured by the change of area of squared membranes given by:

$$
\text { Swelling degree }(\%)=\frac{A_{\text {wet }}-A_{\text {dry }}}{A_{\text {dry }}} \times 100
$$


where $A_{\text {wet }}$ and $A_{\text {dry }}$ refer to the membrane's area after its immersion in deionized water for at least $48 \mathrm{~h}$ at room temperature, and the membrane's area after drying at $120^{\circ} \mathrm{C}$ for at least $24 \mathrm{~h}$, respectively.

The ion-exchange capacity (IEC) was obtained by immersing the swollen membranes in the acid form into a two- $\mathrm{M} \mathrm{NaCl}$ solution. The protons liberated during the exchange reaction were titrated with a $0.01-\mathrm{M} \mathrm{NaOH}$ solution and phenolphthalein. The IEC was calculated as:

$$
\operatorname{IEC}(\mathrm{meq} / \mathrm{g})=\frac{\mathrm{V}_{\mathrm{NaOH}} \times 0.01}{\mathrm{w}_{\mathrm{dry}}} \times 100
$$

where $\mathrm{V}_{\mathrm{NaOH}}$ and $\mathrm{w}_{\text {dry }}$ are the volume of the $\mathrm{NaOH}$ solution (in $\mathrm{mL}$ ) used in the titration of the protons released and grams of dry membrane, respectively. The values of $\mathrm{w}_{\text {dry }}$ were measured after drying the samples immersed within the $\mathrm{NaCl}$ solution at $120^{\circ} \mathrm{C}$ for $24 \mathrm{~h}$.

\section{Results and Discussion}

\subsection{Characterization of Mixed Matrix Membranes}

Field emission scanning electron microscopy (FE-SEM) was used to characterize the particle size of the synthesized ZIF-8 and ZIF-67 materials. As shown in Figure 3A,B, ZIF-8 and ZIF-67 were obtained with an average diameter around $400 \mathrm{~nm}$ and $1250 \mathrm{~nm}$, respectively. Powder X-ray diffraction (PXRD) measurements were carried out for synthesized ZIF-8 and ZIF-67, and the obtained diffraction peaks were correctly attributed with the known XRD pattern for both porous materials (Figure 3C,D) [48]. Attenuated total reflection (ATR) FT-IR was also used to characterize the synthesized materials (Figure 3E). In the FT-IR spectra, the peaks at $2962 \mathrm{~cm}^{-1}$ and $2927 \mathrm{~cm}^{-1}$ can be assigned to $(\mathrm{C}-\mathrm{H})$ stretching, whereas the peak at $1584 \mathrm{~cm}^{-1}$ corresponds to the $\mathrm{C}=\mathrm{N}$ stretching. Finally, the peaks at $763 \mathrm{~cm}^{-1}, 68 \mathrm{~cm}^{-1}, 4 \mathrm{~cm}^{-1}$, and $421 \mathrm{~cm}^{-1}$ are attributed to $(\mathrm{Zn}-\mathrm{O}),(\mathrm{Zn}-\mathrm{N})$, and (Zn-C) stretching, respectively [49]. The porosity of the synthesized ZIF particles was determined via $\mathrm{N}_{2}$ isotherm measurements at $77 \mathrm{~K}$ (Figure 3F). The specific surface areas (BET areas) for ZIF-8, ZIF-67, and ZIF-Mix were found to be 1150, 1375 and 1175, respectively, in accordance with the literature data [50]. Finally, a thermogravimeric analysis (TGA) under a $\mathrm{N}_{2}$ atmosphere was carried out in order to evaluate the materials thermal stability at the operational range $90-120{ }^{\circ} \mathrm{C}$. According to the TGA analysis, ZIF-8 and ZIF-67 were stable up to $350{ }^{\circ} \mathrm{C}$, which make them good candidates to be used as fillers in IT-PEMFCs.
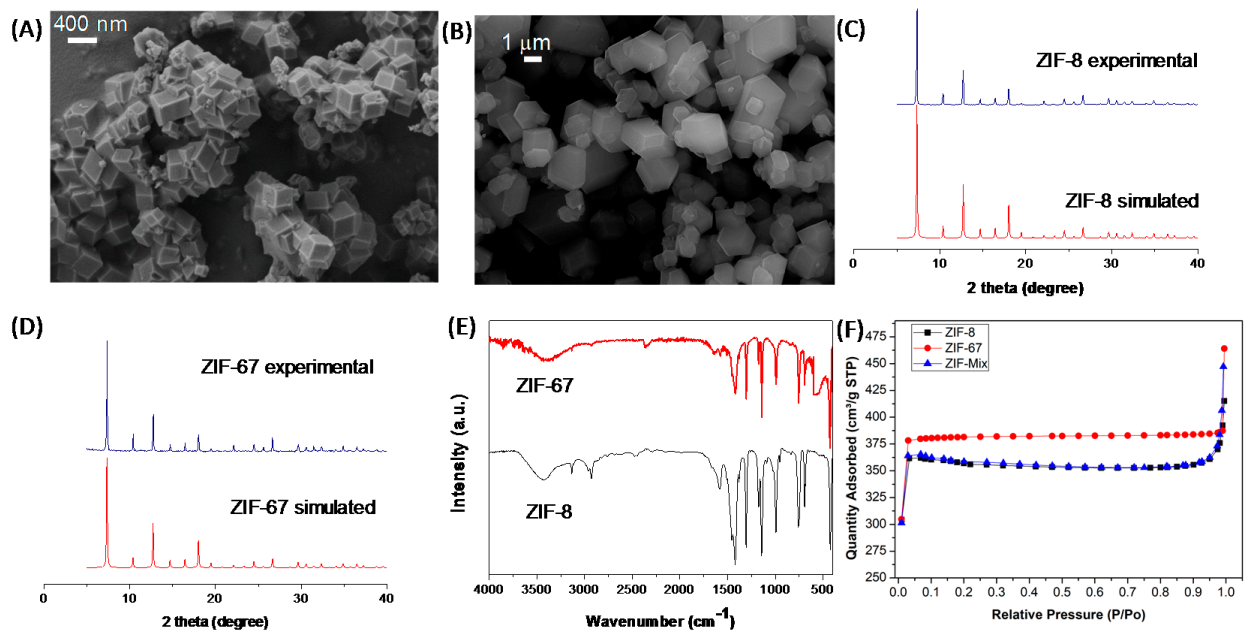

Figure 3. Field emission scanning electron microscopy (FE-SEM) images of (A) ZIF-8 and (B) ZIF-67. (C) XRD patterns of simulated ZIF-8 (red) and ZIF-8 as synthesized (blue). (D) XRD patterns of simulated ZIF-67 (red) and ZIF-67 as synthesized (blue). (E) FT-IR spectra of ZIF-8 and ZIF-67. (E) $\mathrm{N}_{2}$ adsorption-desorption isotherms at $77 \mathrm{~K}$ for ZIF-8, ZIF-67 and ZIF-Mix. 
Next, we prepared composite SPEEK membranes containing both the aforementioned ZIFs, and a 1:1 w:w mixture (ZMix), as described in the Experimental Section. Water molecules are essential in the proton transfer mechanism of PEMs [51]. The water uptake and swelling ratio of composite membranes is shown in Figure 4. The water uptake of a pristine SPEEK membrane was 30\%, which increased upon the addition of ZIF, reaching a maximum at $5 \mathrm{wt}$. \% of filler content for all of the ZIFs under study. The highest water uptake was obtained for the SPEEK/ZMix membrane with a value of $51 \%$. For higher ZIF contents $(10 \%)$, the water uptake of the mixed membranes decreased to values closer than that for the pristine SPEEK membrane. The increase of water uptake at a lower filler content might be caused by the increase of the free volume in the polymeric matrix, which was caused by the addition of ZIFs. On the other hand, the formation of aggregates is favored at higher contents, which hampers an efficient adsorption of water molecules, as observed in mixed matrix membranes with ZIFs and polybenzimidazole (PBI) [52].
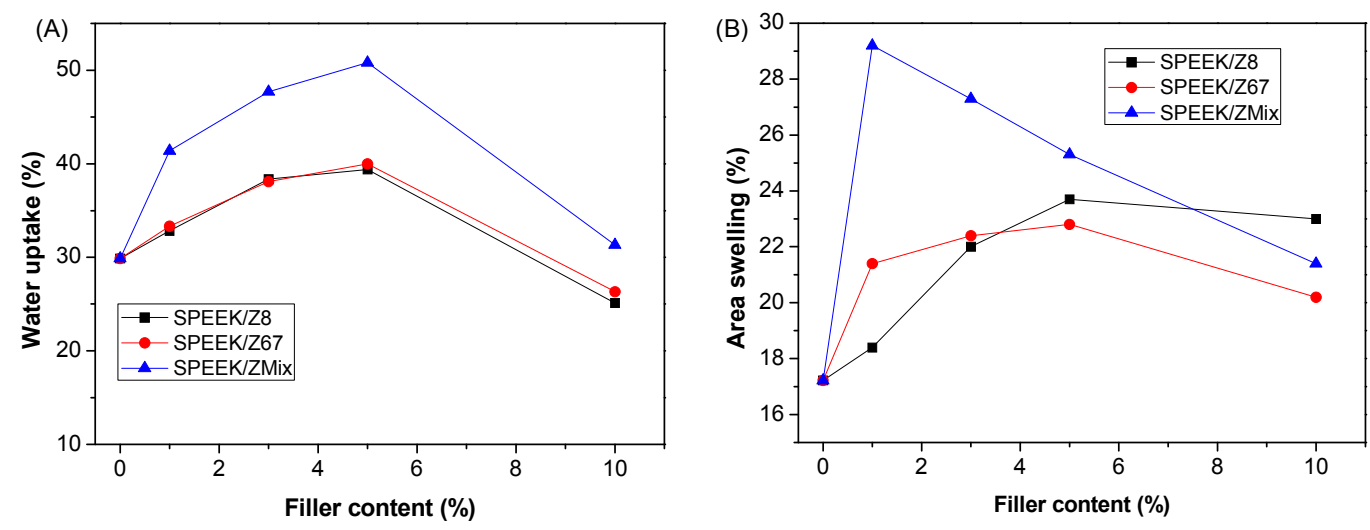

Figure 4. (A) Water uptake and (B) swelling degree of the pristine SPEEK membrane and ZIF-composite membranes with different filler content (wt. \%).

TGA was carried out to study the thermal properties of SPEEK-based membranes with ZIFs, as shown in Figure 5. The thermogram of the different SPEEK/ZIF membranes (SPEEK/Z8, SPEEK/Z67, and SPEEK/ZMix, at ZIF concentrations of $1 \mathrm{wt}$. \%, $3 \mathrm{wt}$. \%, $5 \mathrm{wt}$. \%, and $10 \mathrm{wt}$. \%) display the three thermal stages of membrane decomposition that these polymer-based materials undergo, which is consistent with previous works [53]. The first stage corresponds to the evaporation of the water and residual solvent (DMAc) at the temperature range from $100{ }^{\circ} \mathrm{C}$ to $200{ }^{\circ} \mathrm{C}$ [54]. The next stage corresponds to the thermal desulfonation of SPEEK at 220-380 ${ }^{\circ} \mathrm{C}$. Finally, composite membranes show a decomposition stage above $450{ }^{\circ} \mathrm{C}$, which is attributed to polymer backbone degradation [55]. ZIF-8 and ZIF-67 are stable until temperatures up to $350{ }^{\circ} \mathrm{C}$, and decompose in the temperature range from 400-700 ${ }^{\circ} \mathrm{C}$. However, the MOF degradation is not well defined in the thermogram, as it is masked by the final polymer backbone decomposition stage. In general, the weight loss of composite membranes was higher than that of the pristine membrane, and the total weight loss increased with the increasing content of MOF. It should be noted that although SPEEK composite membranes showed a slightly lower thermal stability than the pure SPEEK membrane, there is not a significant worsening in the operational temperature range $\left(100-140^{\circ} \mathrm{C}\right)$. Therefore, we can conclude that composite membranes possess high thermal stability in the operational range for IT-PEMFC membranes. 

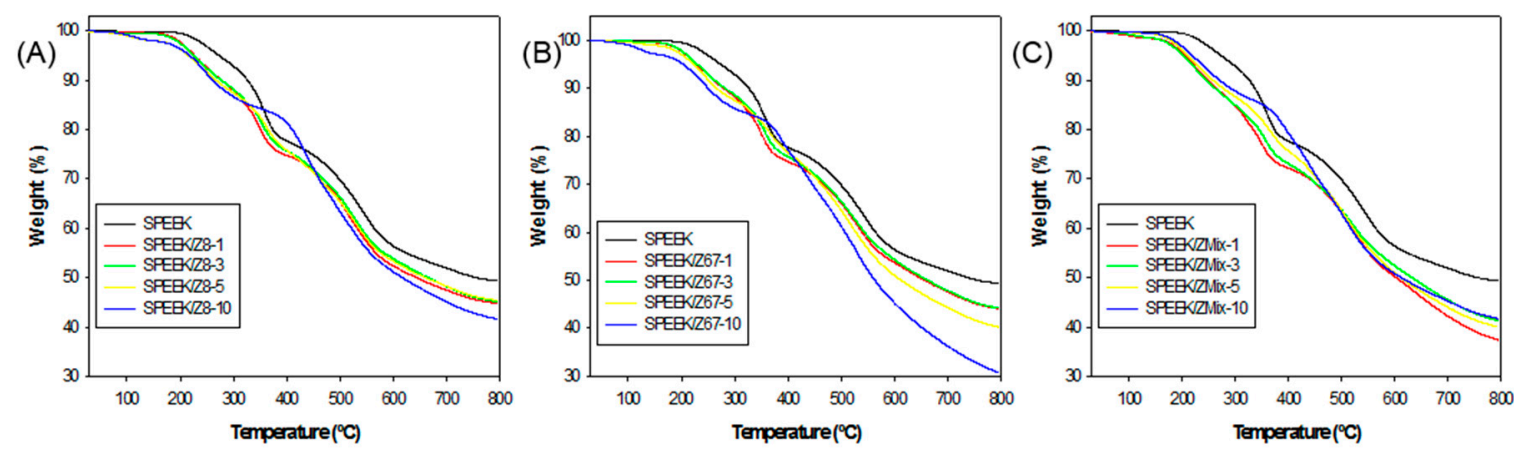

Figure 5. Thermogravimetric analysis (TGA) of the ZIF-composite membranes with different filler content (wt. \%): (A) SPEEK/Z8, (B) SPEEK/Z67 and (C) SPEEK/ZMix.

The stress-strain curves of the prepared SPEEK/ZIF composite membranes at $5 \mathrm{wt}$. \% ZIF loading are shown in Figure 6. As expected, ZIF compounds act as effective reinforcers, increasing the mechanical stability of composite membranes. For example, the Young's modulus increased from 1.5 GPa for the recast SPEEK membrane up to 2.2 GPa for the SPEEK/ZMix-10, which was in combination with an increase of the tensile strength from $95 \mathrm{MPa}$ to $123 \mathrm{MPa}$, respectively (Figure 6A). This enhancement in the mechanical properties can be attributed to the interfacial interactions between ZIFs and the SPEEK polymeric matrix, which may inhibit the mobility of the SPEEK chains, as observed in other SPEEK membranes [56]. In this regard, the good dispersion of ZIFs will play a critical role in improving the mechanical performances, as observed for SPEEK/Z8 and SPEEK/Z67. In both cases, membranes with a filler loading above $5 \mathrm{wt}$. \% yielded a worsening of the mechanical properties. However, in the case of SPEEK/ZMix membranes, the reinforcement is observed above $10 \mathrm{wt}$ \% of ZIF, which was due to the synergistic effect both ZIFs. The elongation at the break values of the SPEEK/ZIF composite membranes was lower than that of the recast SPEEK due to the higher stiffness, which was attributed to the presence of ZIF particles in the polymeric matrix (Figure 6B).

(A)

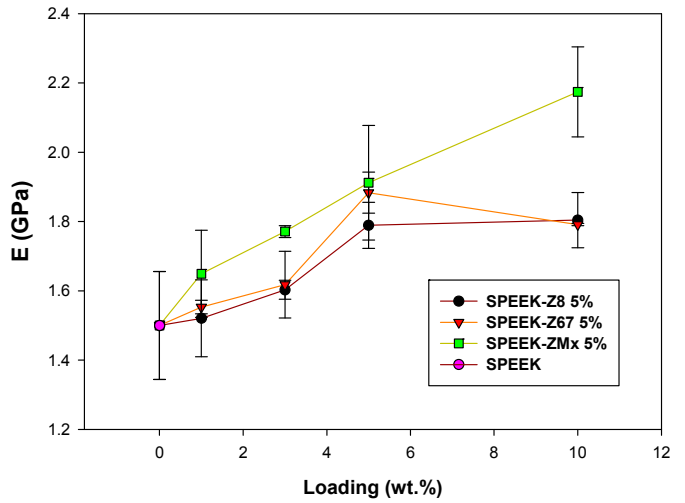

(B)

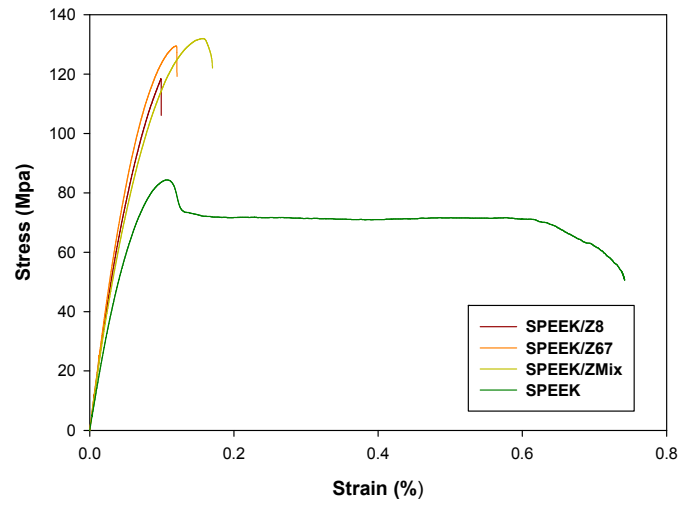

Figure 6. (A) Young modulus and (B) stress-strain curves for pure SPEEK membrane and composite membranes containing $5 \mathrm{wt}$. \% of ZIFs.

\subsection{Proton Conduction of Mixed Matrix Membranes}

Proton conductivity is a key parameter for a PEM, determining fuel cell performance [57]. For this purpose, impedance spectroscopy measurements were carried out on the mixed matrix membranes in saturated humidity conditions at several temperatures in order to obtain the conductivity and diffusivity of the ionic charge carriers. The values of the dc-conductivity $\left(\sigma_{\mathrm{dc}}\right)$ were obtained from the Bode plots along the temperature range between $20-120{ }^{\circ} \mathrm{C}$ for every composite membrane, namely SPEEK/Z8, SPEEK/Z67, and SPEEK/ZMix, at different ZIF concentrations (1\%, 3\%, 5\%, and $10 \%$ ). Figure 7 shows the Bode diagram, in which the real part of the conductivity of the SPEEK/Z8, SPEEK/Z67, and SPEEK/ZMix membranes containing a $3 \mathrm{wt}$. \% filler loading is plotted versus the 
frequency. In this figure, the phase angle $(\phi)$ is also plotted against the frequency to probe that it reached a value close to zero when the real part of the conductivity tend to a plateau, independently of the frequency, which means that this value is the real DC conductivity of the sample.

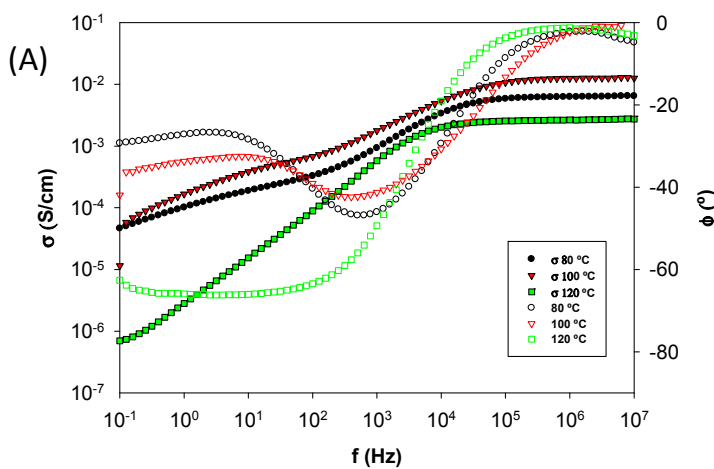

(B)
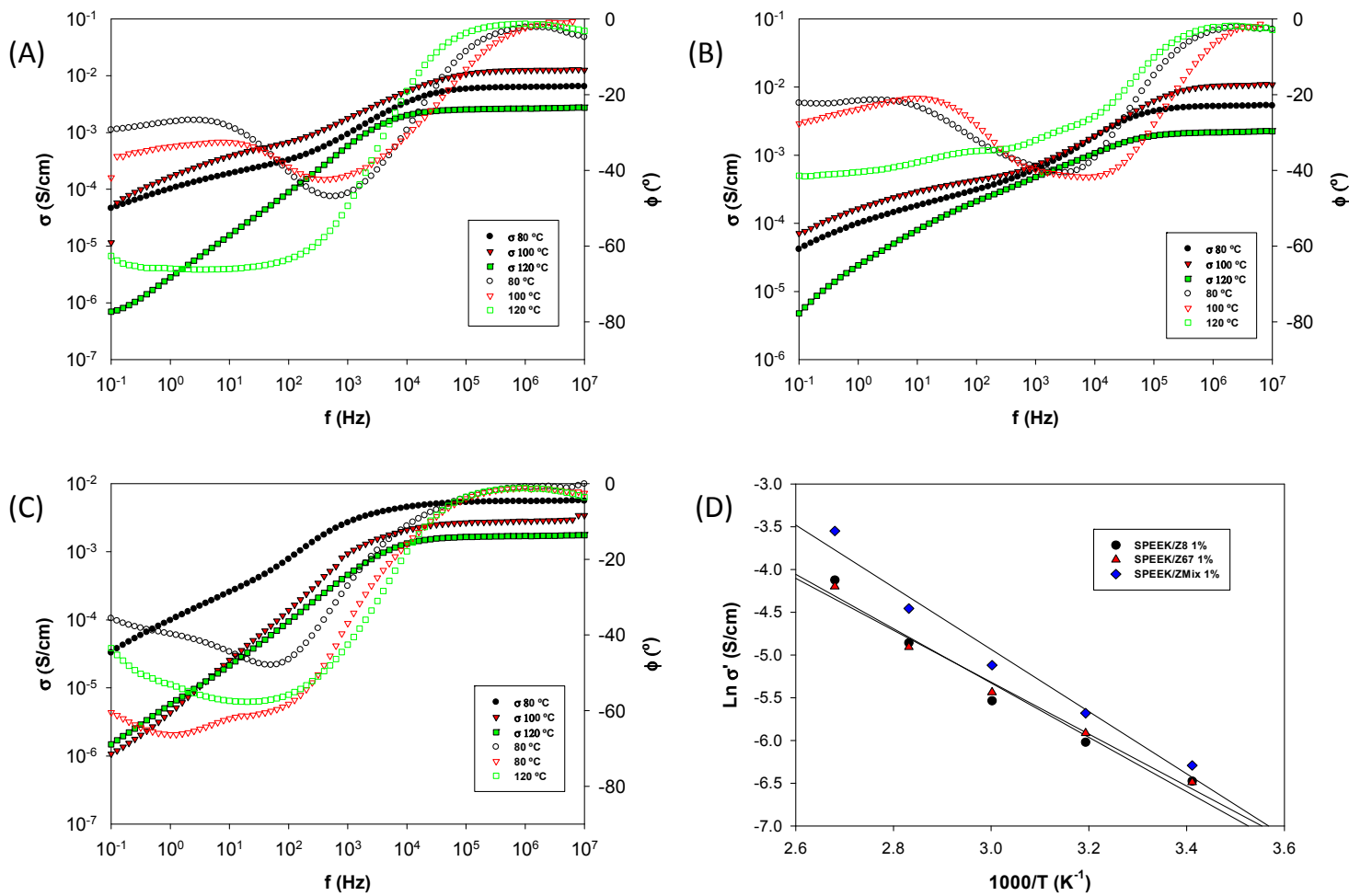

Figure 7. Bode diagrams for the samples: (A) SPEEK/Z8, (B) SPEEK/Z67, and (C) SPEEK/ZMix 3\% at temperatures of $80{ }^{\circ} \mathrm{C}, 100{ }^{\circ} \mathrm{C}$, and $120{ }^{\circ} \mathrm{C}$, respectively. (D) Arrenhius plot of the SPEEK/ZIFs membranes for 3 wt. \% of ZIFs concentration.

A closer inspection of Figure 7 shows that the conductivity increases, with the frequency reaching a plateau in the range of high frequencies for each temperature. The deviation from the plateau, at moderate and low frequencies, can be attributed to the electrode polarization resistance, which results from the blocking of charge carriers at the electrodes [58,59]. On the other hand, the increase of conductivity as a function of temperature can be associated to the thermal activation of proton diffusion. For temperatures higher than $100{ }^{\circ} \mathrm{C}$, the conductivity values dropped as a consequence of the loss of water molecules inside the composite membranes, as observed for measurements at $120^{\circ} \mathrm{C}$. Overall, the prepared SPEEK composite membranes showed a very good conductivity at $100{ }^{\circ} \mathrm{C}$.

From the Bode diagrams, we can observe that thermal activation for the SPEEK/ZMix membrane is stronger than for the SPEEK/Z8 and SPEEK/Z67 composite membranes (Figure 7D). The comparison between the different composite membranes show that SPEEK/ZMix at $1 \%$ has a conductivity of $1.9 \times 10^{-3} \mathrm{~S} \cdot \mathrm{cm}^{-1}$ and $2.9 \times 10^{-2} \mathrm{~S} \cdot \mathrm{cm}^{-1}$ at $20^{\circ} \mathrm{C}$ and $100^{\circ} \mathrm{C}$, respectively. These values are higher than the conductivity of SPEEK/Z8 $\left(1.5 \times 10^{-3} \mathrm{~S} \cdot \mathrm{cm}^{-1}\right.$ and $\left.1.6 \times 10^{-2} \mathrm{~S} \cdot \mathrm{cm}^{-1}\right)$ and for SPEEK/Z67 membranes at the same filler loading $\left(1.5 \times 10^{-3} \mathrm{~S} \cdot \mathrm{cm}^{-1}\right.$ and $\left.1.5 \times 10^{-2} \mathrm{~S} \cdot \mathrm{cm}^{-1}\right)$. All of these values are greater than pristine SPEEK $\left(1.5 \times 10^{-4} \mathrm{~S} \cdot \mathrm{cm}^{-1}\right.$ and $\left.2.0 \times 10^{-4} \mathrm{~S} \cdot \mathrm{cm}^{-1}\right)$. Our composite membranes of SPEEK/ZIFs show better conductivity results than those observed in the composite membranes of PEI/ZIFs, where the same powders were used as fillers [60]. The difference could be related to the concentrations of mobile carriers and its mobility. As is known, the conductivity is related to protons, as a consequence of the sulfonic acid incorporated upon the PEEK sulfonation. As observed in similar systems [60], the local anisotropic electric field in the ZMix material may explain the increase of concentration of carriers, consequently favoring the conduction process into the composite membranes. 
The activation plot for the proton conductivity as a function of temperature for the composite membranes shows clearly an Arrhenius behavior in all of the cases. The apparent activation energy values that were obtained for the three ZIFs materials were similar, with a decrease in the activation energy (Ea) values as the amount of ZIF increased. In the case of SPEEK/ZMx, reaching some critical value of concentration required above $10 \% \mathrm{wt}$, when the Ea changed its tendency, increasing its values. The Ea trend for a $3 \mathrm{wt}$. \% loading is as follows: Ea (SPEEK/Zmix) $=(23.1 \pm 1.3) \mathrm{kJ} / \mathrm{mol}(0.24 \pm 0.01)$ $\mathrm{eV}<\mathrm{Ea}(\mathrm{SPEEK} / \mathrm{Z} 67)=(25.9 \pm 1.5) \mathrm{kJ} / \mathrm{mol}(0.27 \pm 0.01) \mathrm{eV}<\mathrm{Ea}(\mathrm{SPEEK} / \mathrm{Z} 8)=(27.2 \pm 1.7) \mathrm{kJ} / \mathrm{mol}$ $(0.28 \pm 0.02) \mathrm{eV}$. These values are lower than those found for the activation energy of the conductivity of other MOFs-based proton membranes [61,62]. The obtained activation energy values lie in the range of Ea $<0.4 \mathrm{eV}$, which corresponds to the typical Grotthuss mechanism. As the ZIF loading increases, two different effects can be considered. First, less charge carriers are available for ionic transport, since they are participating in intermolecular hydrogen bonds with the nitrogen of the imidazolate linker of ZIF. As a consequence, water uptake increases for the composite membranes at low concentrations of ZIF, which is due to the increase of free volume motivated for the introduction of the ZIF particles among the polymeric chains. This effect has been described in other systems where there is not a phase of protons dispersed to favor the vehicular transport of electrolyte $[63,64]$.

According to the Grotthuss mechanism, the conduction mechanism for a pristine SPEEK membrane can be rationalized through the transfer of protons that are linked to the sulfonic groups from the SPEEK polymeric chain. These protons may combine with water molecules to form the hydronium cation $\left(\mathrm{H}_{3} \mathrm{O}^{+}\right)$. Next, a proton of the hydronium cation is transferred to another water molecule bonded to a nearby sulfonic acid group. Under anhydrous conditions, the absence of water molecules hampers the proton conduction, as protons cannot move though a hydrogen bond network. In the case of ZIF composite SPEEK membranes, ZIFs can participate in the conduction process, forming a hydrogen bond network along the polymeric matrix, and facilitating the transport, even under anhydrous conditions.

In these composite materials containing ZIF particles, we hypothesized that the ZIF dispersion along a sulfonated polymer such as SPEEK produces an interface layer that can help accumulate water molecules, and therefore facilitate the conductivity of protons by means of the increase of the water uptake and the hydrophilicity of the material. Then, hydrogens have more freedom to participate in the proton transport; furthermore, the activation energy decreases, in combination with a decrease of the conductivity, less charge carriers are present in the system. This behavior is observed up to a critical concentration, when the mobility of protons is too restricted due to the interactions of the protons with the organic linkers. This behavior is also observed for the steric bulk of the ZIF aggregates, which are observed at high loadings and can contribute to a separation of the polymeric membrane in hydrophilic and hydrophobic domains. This phase separation may hamper the proton transport, and therefore cause a decrease in proton conductivity, as observed experimentally.

\subsection{Determination of Diffusion Coefficient and Ion Concentration}

Although different electrode polarization (EP) models have been described to determine the mobility and ionic concentration of charge carriers in polymeric membranes using impedance spectroscopy measurements [65-70], we focused on the method proposed by Bandara et al. [71] to analyze the conduction phenomena in our composite membranes. This model is based on a previous model described by Coelho [72], in which the ionic charge density and the ion mobility are obtained from measurements of $\tan \delta$ in ionic conductors and polymeric membranes [73]. According to Bandara's model, the dependence of the complex dielectric permittivity $\left(\varepsilon^{*}\right)$ with the frequency for a material sandwiched between two blocking electrodes is represented by:

$$
\varepsilon^{*}=\varepsilon_{\infty}^{\prime}\left[\left(1+\frac{\mathrm{M}}{1+\left(\omega \tau_{\mathrm{m}}\right)^{2} \mathrm{M}}\right)\right]-\mathrm{j}\left(\frac{\omega \tau_{\mathrm{m}} \mathrm{M}^{3 / 2}}{1+\left(\omega \tau_{\mathrm{m}}\right)^{2} \mathrm{M}}\right)
$$


where $\mathrm{M}$ is given by:

$$
\mathrm{M}=\frac{\mathrm{L}}{2\left(\mathrm{D} \tau_{\mathrm{m}}\right)^{1 / 2}}=\frac{\mathrm{L}}{2 \lambda}
$$

where $L$ is the sample thickness, $\lambda$ is the Debye length, $\varepsilon_{\infty}^{\prime}$ is the real part of the permittivity at high frequencies, and $\tau_{\mathrm{m}}$ is the time constant, corresponding to the maximum dielectric loss tangent. This time represents the relaxation time associated with the charge diffusion process into the sample $[74,75]$.

From the real and imaginary part of the complex permittivity $(\varepsilon)$, the following expression for Debye type relaxation can be obtained for the loss $\tan \delta=\varepsilon^{\prime \prime} / \varepsilon^{\prime}$ :

$$
\tan \delta=\frac{\omega \tau_{\mathrm{m}} \mathrm{M}^{3 / 2}}{1+\left(\omega \tau_{\mathrm{m}}\right)^{2} \mathrm{M}+\mathrm{M}} \cong \frac{\omega \tau_{\mathrm{m}} \mathrm{M}^{1 / 2}}{1+\left(\omega \tau_{\mathrm{m}}\right)^{2}}
$$

However, to take account of the peaks' width, we have fit our curves by means of a Cole-Cole type model [76], and we have introduced the following modification in Equation (6). Therefore, $\tan \delta$ can be given by the following expression:

$$
\tan \delta=\frac{\left(\omega \tau_{\mathrm{m}}\right)^{(1-\alpha)} \mathrm{M}^{3 / 2}}{1+\left(\omega \tau_{\mathrm{m}}\right)^{2(1-\alpha)} \mathrm{M}+\mathrm{M}} \cong \frac{\left(\omega \tau_{\mathrm{m}}\right)^{(1-\alpha)} \mathrm{M}^{1 / 2}}{1+\left(\omega \tau_{\mathrm{m}}\right)^{2(1-\alpha)}}
$$

Figure 8 shows the plot of $\tan \delta$ as a function of the frequency for the samples SPEEK/Z8, SPEEK/Z67, and SPEEK/ZMix at $5 \mathrm{wt}$. \% loading along temperature range between $20-120{ }^{\circ} \mathrm{C}$. As observed in Figure 8, a clear maximum in the curves can be observed for each temperature, and this maximum is abruptly shifted to high frequencies, as the temperature increases up to $100{ }^{\circ} \mathrm{C}$. Upon reaching this temperature, the maximum in the $\tan \delta$ plot is shifted to lower frequencies.

(A)

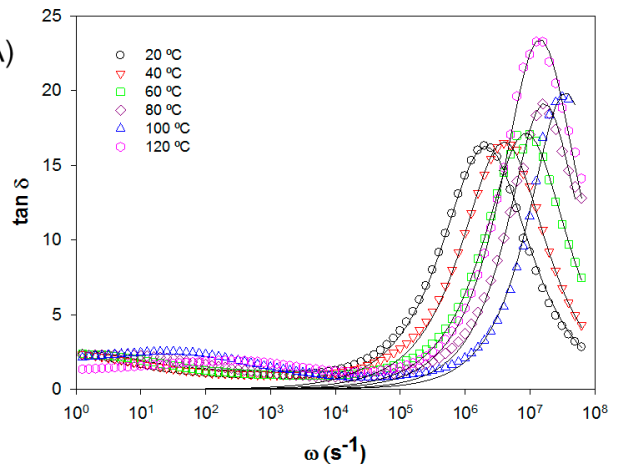

(C)

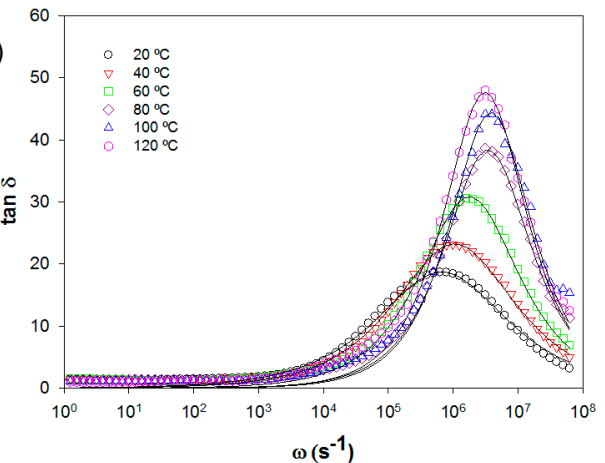

(B)

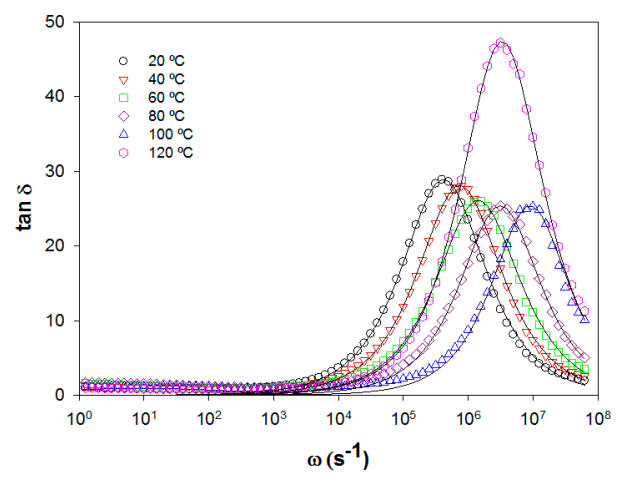

(D)

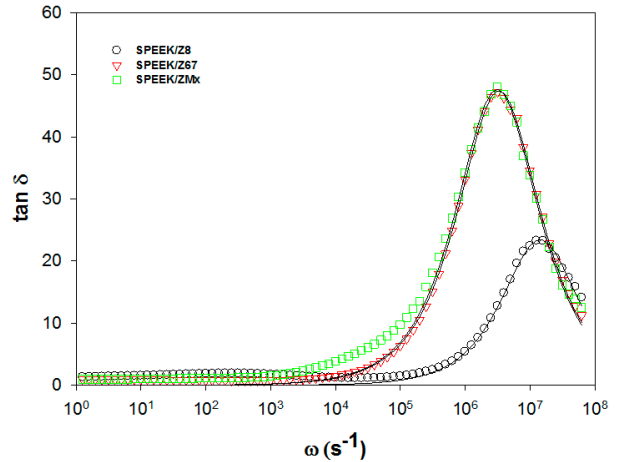

Figure 8. Tan $\delta$ vs. frequency in all the range of temperatures for $5 \%$ loading (A) SPEEK/Z8, (B) SPEEK/Z67, (C) SPEEK/ZMix, and (D) the three different ZIFs studied at $120^{\circ} \mathrm{C}$ at $5 \mathrm{wt}$. \% loading.

When comparing the intensity of the loss of $\tan \delta$ for the different composites, several effects are observed. First, the peak of the maximum in $\tan \delta$ varies from 10 to 20 for the SPEEK/Z8 membrane, 
and from 20 to 30 in case of the SPEEK/Z67 membrane, when the temperature increases from $20^{\circ} \mathrm{C}$ to $120^{\circ} \mathrm{C}$. On the contrary, for the composite SPEEK/ZMix membrane, the peaks of tan $\delta$ are wider than those observed for the other two cases. The width frequency at low temperatures changes between four or five orders of magnitude, and its intensity is lower than those for the SPEEK/Z8 and SPEEK/Z67 membranes. This observation suggests that the height and width of the peaks in tan $\delta$ are strongly related to the structure of the membranes. In our case, we have a decrease in the charge carriers when the amount of ZIFs increases due to the interaction between hydrogens from the sulfonic acid groups contained in the polymeric chains and nitrogen atoms from the organic linkers of ZIF compounds. These observations are in agreement with the observed IEC values. On the other hand, the hydrophobicity of ZIFs leads to the build up of aggregates, which get worse with the increase in charge transport. This effects cause a decrease of the amount of available charge carriers, which is reflected in a bigger distribution of relaxation times, producing a decrease in the peaks' intensity and an increasing of the peak width. These effects are more evident when the interaction of the charge carriers grows with the increase of the ZIF loading. This phenomenon is very evident in the case of the samples containing ZIF-Mix at $10 \mathrm{wt}$. \% at low temperatures.

When the concentration of ZIFs is above some critical value, we can see two peaks in the plot of Figure 8. It is due to the appearance of two different processes for the conductivity. Firstly, at low frequencies, some amount of dipoles cannot move with the electric field that is applied, due to the restrained mobility of the ions into the Debye length layer as a consequence of the opposite electric force created by the charges of the same sign. When the frequency increase appears, a second peak appears that is related to the DC conductivity of the membrane. This effect is dependent on the temperature producing an enhancement of the conductivity, and disappears with an increase in the temperature, since the electric interactions are broken; then only a peak in $\tan \delta$ at high frequencies is observed, such as that which is observed from Figure 8.

In the present work, Equation (7) has been used to fit the experimental data shown in Figure 8 and obtain an estimation for the parameters $M$ and $\tau_{m}$, for all of the temperatures. The values of these parameters are given in Table 1.

Table 1. Calculated parameters $M$ and $\tau_{m}$ obtained from fitting experimental data of tan $\delta$ for the composite membranes SPEEK/Z8, SPEEK/Z67, and SPEEK/ZMix at 1 wt. \% filler loading.

\begin{tabular}{|c|c|c|c|c|c|c|c|c|c|}
\hline \multirow[t]{2}{*}{ Membrane } & \multicolumn{3}{|c|}{$\mathrm{T}=40^{\circ} \mathrm{C}$} & \multicolumn{3}{|c|}{$\mathrm{T}=80^{\circ} \mathrm{C}$} & \multicolumn{3}{|c|}{$\mathrm{T}=120^{\circ} \mathrm{C}$} \\
\hline & $\mathbf{M}$ & $\begin{array}{c}\tau_{\mathrm{m}} \times \\
10^{7} \text { (s) }\end{array}$ & $\begin{array}{c}\mathrm{D} \times 10^{7} \\
\left(\mathrm{~cm}^{2} / \mathrm{s}\right)\end{array}$ & $\mathbf{M}$ & $\begin{array}{c}\tau_{\mathrm{m}} \times \\
10^{7}(\mathrm{~s})\end{array}$ & $\begin{array}{c}\mathrm{D} \times 10^{7} \\
\left(\mathrm{~cm}^{2} / \mathrm{s}\right)\end{array}$ & $\mathbf{M}$ & $\begin{array}{c}\tau_{\mathrm{m}} \times \\
10^{7}(\mathrm{~s})\end{array}$ & $\begin{array}{c}\mathrm{D} \times 10^{7} \\
\left(\mathrm{~cm}^{2} / \mathrm{s}\right)\end{array}$ \\
\hline SPEEK/Z8 & 790 & 2.00 & 80.1 & 12,580 & 0.35 & 1.81 & 19,000 & 1.30 & 0.21 \\
\hline SPEEK/Z67 & 990 & 3.0 & 76.5 & 3420 & 1.00 & 19.2 & 5200 & 2.50 & 3.33 \\
\hline SPEEK/ZMix & 1580 & 7.00 & 5.16 & 11,460 & 0.8 & 0.6 & 18,800 & 1.18 & 0.22 \\
\hline
\end{tabular}

A closer inspection of Table 1 also permits observing that the relaxation time $\tau_{\mathrm{m}}$ and the parameter $\mathrm{M}$ strongly depend on the temperature. The relaxation time $\left(\tau_{\mathrm{m}}\right)$ decreases with the temperature increase, whereas the parameter $\mathrm{M}$ increases. Figure 8 shows the fitting for three composite membranes-SPEEK/Z8, SPEEK/Z67, and SPEEK/ZMix_for a ZIF loading of 5 wt. \% at different temperatures. The solid lines indicate the convolution of Equation (4) in the peak of $\tan \delta$ at higher frequencies. As can be seen, curves display peaks corresponding to the maxima in $\tan \delta$, which are associated with the plateau of the real part of the conductivity observed in the Bode diagrams (Figure 7). Regardless of the model used, the value of the frequency of the peaks in $\tan \delta$ corresponding to values in frequency are the same and related with the parameters $M$ and $\tau_{\mathrm{m}}$ as:

$$
\omega_{\max }^{\tan \delta}=\frac{1}{\tau_{\mathrm{m}}}
$$

The $\mathrm{M}$ parameter can also be expressed as $\mathrm{M}=\mathrm{L} / 2 \mathrm{~L}_{\mathrm{D}}$, and the parameters $\tau_{\mathrm{m}}$ and $\varepsilon_{\mathrm{EP}}$ are related to $\mathrm{M}$ through the expressions $\tau_{\mathrm{m}}=\mathrm{M}^{1 / 2} \cdot \tau$, with $\tau$ being the relaxation time, which is also defined as 
$\sigma=\varepsilon_{S} / \sigma_{\mathrm{dc}}$, where $\varepsilon_{\mathrm{S}}$ is the dielectric permittivity of the sample $[66,68]$. The parameter $\mathrm{L}$ is the thickness of the sample (i.e., electrode separation when the sample is sandwiched to take the measurements), and $L_{D}$ is the Debye length, which can be defined as:

$$
\mathrm{L}_{\mathrm{D}}=\sqrt{\frac{\varepsilon_{S} \varepsilon_{0} k T}{\mathrm{q}^{2} \mathrm{n}}}
$$

where $\mathrm{k}$ is the Boltzmann constant, $\mathrm{T}$ is the absolute temperature, $\mathrm{q}$ is the ion charge, and $n$ is the mobile charge density.

Considering that cations and anions have approximately the same mobility $\mu$, the conductivity $\sigma_{\mathrm{dc}}$ can be expressed in terms of $\mathrm{n}$ and $\mu$ according to the following expression:

$$
\sigma_{\mathrm{dc}}=\mathrm{nq \mu}
$$

and the ion mobility can be determined as:

$$
\mu=\frac{\mathrm{qL}^{2}}{4 \mathrm{M} \tau_{\mathrm{m}} \mathrm{kT}}
$$

Finally, considering the Einstein relation for ion diffusivity in combination with Equation (10) and Equation (11), the diffusion coefficient of the protons can be expressed as:

$$
\mathrm{D}=\frac{\mathrm{L}^{2}}{4 \mathrm{M}^{2} \tau_{\mathrm{m}}}
$$

The use of Equation (12) allows calculating the ion diffusivity in terms of parameters such as $\mathrm{M}$ $\tau_{\mathrm{m}}$ and L. From equations (10) and (12), the ionic charge density (n) is calculated as:

$$
\mathrm{n}=\frac{\sigma_{\mathrm{dc}} \mathrm{kT}}{\mathrm{Dq}^{2}}
$$

The calculated values for diffusivity $D$ and charge density $n$ as a function of the temperature are shown in Figure 9. From Figure 9A, we can observe a similar effect in diffusivity $D$ to that observed in conductivity. For SPEEK/Z8 and SPEEK/Z67 membranes, the diffusivity rises as the temperature increases; however, an abrupt decrease in the calculated diffusivity happens at $120^{\circ} \mathrm{C}$, which can be attributed to the dehydration of the membrane. Contrarily, for the SPEEK/ZMix membrane, the diffusivity decreases as the temperature increases.

(A)

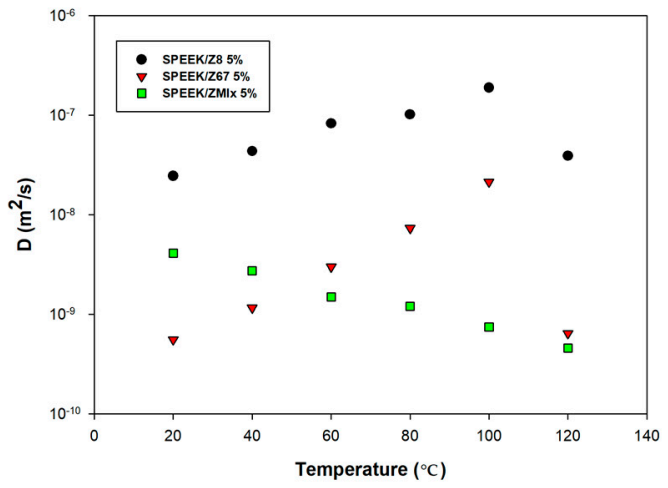

(B)

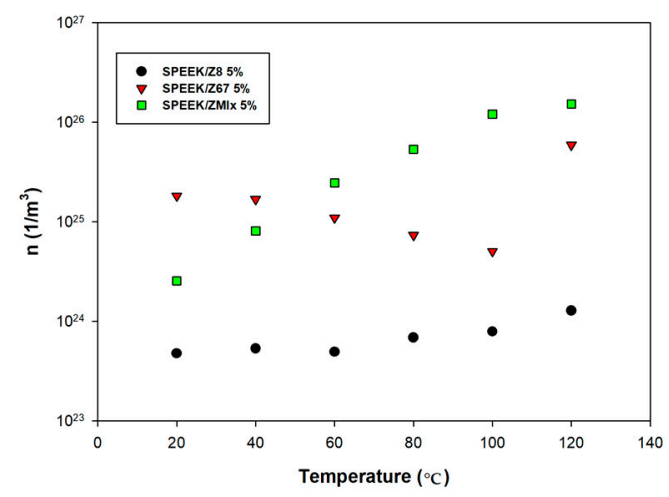

Figure 9. (A) Plot of diffusivity vs. temperature and (B) plot of charge density vs. temperature for SPEEK composite membranes with a ZIF loading of $5 \mathrm{wt}$ \%.

Assuming the electrolyte is univalent, we have obtained the values of diffusion coefficients from the previously determined values of $M$ and $\tau_{m}$, which are in agreement with Equation (12). The 
values that are found are reasonably similar to those compared with other systems, and decrease at higher temperatures.

Finally, the values of free-ion density have been determined through combining the values of DC-conductivity obtained from Bode diagrams and the values of diffusion coefficients calculated according to Equation (12). Our results showed that the calculated charge concentration density increases with temperature for the SPEEK/ZMix sample, which is practically constant for the SPEEK/ZIF8 sample and slightly decrease for the SPEEK/ZIF67 sample. Such results can be related to the different structures and compositions of the fillers, with the cross-linking and solvent. The results that were observed are in agreement with the behavior observed for the composites membranes of PEI/ZIFs [77,78]. From the Arrhenius fit of the free-ion density, we have estimated the dissociation energy. In general, for SPEEK/Z8 and SPEEK/Z67, the value of dissociation energy decreases when the concentration of ZIFs increases, yielding for SPEEK/Z8 $1 \mathrm{wt}$. \% and SPEEK/Z8 $10 \mathrm{wt} . \%, 0.80 \pm 0.01 \mathrm{eV}$ and $0.12 \pm 0.01 \mathrm{eV}$ and $0.67 \pm 0.08 \mathrm{eV}$ and $0.06 \pm 0.02 \mathrm{eV}$ for SPEEK/Z67 at $1 \mathrm{wt}$. \% and $10 \mathrm{wt} . \%$ loading, respectively. The tendency is different for SPEEK/ZMix that has the highest value for $10 \%$ concentration of ZIF with a dissociation energy of $0.70 \pm 0.14 \mathrm{eV}$. When we compared the composite membranes at one concentration, the tendency is SPEEK/Z8 > SPEEK/Z67 > SPEEK/ZMix at lower concentrations, and shows an opposite behavior at higher concentrations.

\section{Conclusions}

In summary, we have prepared and characterized polymeric composite membranes based on SPEEK containing three MOFs (ZIF-8, ZIF-67, and ZIF-Mix) as fillers at different loadings by means of water uptake, swelling ratio, IEC, TGA, and EIS. The charge transport mechanism has been studied through an electrode polarization model applied over experimental data, according to the methodology followed by Bandara et al., which fit the $\tan \delta=\varepsilon^{\prime \prime} / \varepsilon^{\prime}$ versus frequency. From the analysis of results, we have found that a bit overestimates free ion diffusivity, while underestimating the free-ion number density, although the values are in the same range as those reported in other systems studied with a Trukhan electrode polarization model.

Proton conductivity showed a dependence on the ZIFs content, reaching values as high as $29 \mathrm{mS} \cdot \mathrm{cm}^{-1}$ at $100{ }^{\circ} \mathrm{C}$ for a SPEEK/ZMix at $1 \mathrm{wt}$. \%. Interesting values of conductivity were observed for all of the samples. These conductivity values indicate that these composite membranes represent a promising alternative to Nafion for its application in different energy devices. These results, in combination with their thermal stability and good physicochemical properties, make them potential candidates to operate as IT-PEMFCs.

Author Contributions: V.C. and E.G. conceived the idea and guided the project. A.B. performed the membrane preparation, characterization and analyzed the data. J.E. and A.A. helped in the experimental measurements and data analyses. All authors discussed the results. A.B., J.E. and V.C. The last wrote the paper and help to A.B. in the analysis of impedance spectroscopy measurements. Finally, all authors commented on the manuscript and provided feedback. All authors have given approval to the final version of the manuscript.

Funding: This work was funded by The Spanish Ministerio de Economía y Competitividad (MINECO) under the project ENE/2015-69203-R.

Acknowledgments: The authors acknowledge Óscar Sahuquillo and Abel García-Bernabé (both from Universitat Politècnica de València) for technical assistance with TGA analysis and with the EIS measurements, respectively.

Conflicts of Interest: The authors declare no conflict of interest.

\section{References}

1. Veziroglu, A.; Macario, R. Fuel cell vehicles: State of the art with economic and environmental concerns. Int. J. Hydrogen Energy 2011, 36, 25-43. [CrossRef]

2. Granovskii, M.; Dincer, I.; Rosen, M.A. Environmental and economic aspects of hydrogen production and utilization in fuel cell vehicles. J. Power Sources 2006, 157, 411-421. [CrossRef] 
3. Kraytsberg, A.; Ein-Eli, Y. Review of advanced materials for proton exchange membrane fuel cells. Energy Fuels 2014, 28, 7303-7330. [CrossRef]

4. Wang, Y.; Chen, K.S.; Mishler, J.; Cho, S.C.; Adroher, X.C. A review of polymer electrolyte membrane fuel cells: Technology, applications, and needs on fundamental research. Appl. Energy 2011, 88, 981-1007. [CrossRef]

5. Álvarez, G.; Alcaide, F.; Cabot, P.L.; Lázaro, M.J.; Pastor, E.; Solla-Gullóne, J. Electrochemical performance of low temperature PEMFC with surface tailored carbon nanofibers as catalyst support. Int. J. Hydrogen Energy 2012, 37, 393-404. [CrossRef]

6. Li, Q.F.; He, R.H.; Jensen, J.O.; Bjerrum, N.J. Approaches and recent development of polymer electrolyte membranes for fuel cells operating above $100{ }^{\circ} \mathrm{C}$. Chem. Mater. 2003, 15, 4896-4915. [CrossRef]

7. Rasheed, R.K.A.; Liao, Q.; Zhang, C.; Chan, S.H. A review on modelling of high temperature proton exchange membrane fuel cells (HT-PEIVIFCs). Int. J. Hydrogen Energy 2017, 42, 3142-3165. [CrossRef]

8. Quartarone, E.; Angioni, S.; Mustarelli, P. Polymer and composite membranes for proton-conducting, high-temperature fuel cells: A critical review. Materials 2017, 10, 687. [CrossRef]

9. Steele, B.C.; Heinzel, A. Materials for fuel-cell technologies. Nature 2001, 414, 345-352. [CrossRef]

10. Mauritz, K.A.; Moore, R.B. State of understanding of Nafion. Chem. Rev. 2004, 104, 4535-4585. [CrossRef]

11. Casciola, M.; Alberti, G.; Sganappa, M.; Narducci, R. On the decay of Nafion proton conductivity at high temperature and relative humidity. J. Power Sources 2006, 162, 141-145. [CrossRef]

12. Dupuis, A.-C. Proton exchange membranes for fuel cells operated at medium temperatures: Materials and experimental techniques. Prog. Mater. Sci. 2011, 56, 289-327. [CrossRef]

13. Li, Q.; He, R.; Gao, J.-A.; Jensen, J.O.; Bjerrum, N.J. The CO poisoning effect in PEMFCs operational at temperatures up to $200{ }^{\circ} \mathrm{C}$. J. Electrochem. Soc. 2003, 150, A1599-A1605. [CrossRef]

14. Sun, B.; Song, H.; Qiu, X.; Zhu, W. New anhydrous proton exchange membrane for intermediate temperature proton exchange membrane fuel cells. ChemPhysChem 2011, 12, 1196-1201. [CrossRef] [PubMed]

15. Zaidi, S.M.J.; Mikhailenko, S.D.; Robertson, G.P.; Guiver, M.D.; Kaliaguine, S. Proton conducting composite membranes from polyether ether ketone and heteropolyacids for fuel cell applications. J. Membr. Sci. 2000, 173, 17-34. [CrossRef]

16. Iulianelli, A.; Basile, A. Sulfonated PEEK-based polymers in PEMFC and DMFC applications: A review. Int. J. Hydrogen Energy 2012, 37, 15241-15255. [CrossRef]

17. Nag, S.; Castro, M.; Choudhary, V.; Feller, J.F. Sulfonated poly(ether ether ketone) [SPEEK] nanocomposites based on hybrid nanocarbons for the detection and discrimination of some lung cancer VOC biomarkers. J. Mater. Chem. B 2017, 5, 348-359. [CrossRef]

18. Neburchilov, V.; Martin, J.; Wang, H.; Zhang, J. A review of polymer electrolyte membranes for direct methanol fuel cells. J. Power Sources 2007, 169, 221-238. [CrossRef]

19. Paddison, S.J. Proton conduction mechanisms at low degrees of hydration in sulfonic acid-based polymer electrolyte membranes. Annu. Rev. Mater. Res. 2003, 33, 289-319. [CrossRef]

20. Dechnik, J.; Gascon, J.; Doonan, C.J.; Janiak, C.; Sumby, C.J. Mixed-matrix membranes. Angew. Chem. Int. Ed. 2017, 56, 9292-9310. [CrossRef]

21. Reyes-Rodriguez, J.L.; Escorihuela, J.; García-Bernabé, A.; Giménez, E.; Solorza-Feria, O.; Compañ, V. Proton conducting electrospun sulfonated polyether ether ketone graphene oxide composite membranes. RSC Adv. 2017, 7, 53481-53491. [CrossRef]

22. Zhang, Z.; Han, S.; Wang, C.; Li, J.; Xu, G. Single-Walled Carbon Nanohorns for Energy Applications. Nanomaterials 2015, 5, 1732-1755. [CrossRef] [PubMed]

23. Wang, Y.; Wei, H.; Lu, Y.; Wei, S.; Wujcik, E.K.; Guo, Z. Multifunctional carbon nanostructures for advanced energy storage applications. Nanomaterials 2015, 5, 755-777. [CrossRef] [PubMed]

24. Du, L.; Yan, G.; He, G.; Wu, X.; Hu, Z.; Wang, Y. SPEEK proton exchange membranes modified with silica sulfuric acid nanoparticles. Int. J. Hydrogen Energy 2012, 37, 11853-11861. [CrossRef]

25. Venkatesana, P.N.; Dharmalingam, S. Effect of zeolite on SPEEK/zeolite hybrid membrane as electrolyte for microbial fuel cell applications. RSC Adv. 2015, 5, 84004-84013. [CrossRef]

26. Fuentes, I.; Andrio, A.; García-Bernabé, A.; Escorihuela, J.; Viñas, C.; Teixidor, F.; Compañ, V. Structural and dielectric properties of cobaltacarborane composite polybenzimidazole membranes as solid polymer electrolytes at high temperature. Phys. Chem. Chem. Phys. 2018, 20, 10173-10184. [CrossRef] [PubMed] 
27. Phang, W.J.; Jo, H.; Lee, W.R.; Song, J.H.; Yoo, K.; Kim, B.; Hong, C.S. Superprotonic conductivity of a UiO-66 framework functionalized with sulfonic acid groups by facile postsynthetic oxidation. Angew. Chem. Int. Ed. 2015, 54, 5142-5146. [CrossRef]

28. Ramaswamy, P.; Wong, N.E.; Gelfand, B.S.; Shimizu, G.K.H. A water stable magnesium MOF that conducts protons over $10^{-2} \mathrm{~S} \mathrm{~cm}^{-1}$. J. Am. Chem. Soc. 2015, 137, 7640-7643. [CrossRef]

29. Escorihuela, J.; Narducci, R.; Compañ, V.; Costantino, F. Proton conductivity of mixed membranes with metal-organic frameworks in proton exchange membranes for fuel cell applications. Adv. Mater. Interfaces 2019, 6. [CrossRef]

30. Furukawa, H.; Cordova, K.E.; O'Keeffe, M.; Yaghi, O.M. The chemistry and applications of metal-organic frameworks. Science 2013, 341, 974. [CrossRef]

31. James, S.L. Metal-organic frameworks. Chem. Soc. Rev. 2003, 32, 276-288. [CrossRef] [PubMed]

32. Wang, B.; Xie, L.-H.; Wang, X.; Liu, X.-M.; Li, J.; Li, J.-R. Applications of metal-organic frameworks for green energy and environment: New advances in adsorptive gas separation, storage and removal. Green Energy Environ. 2018, 3, 191-228. [CrossRef]

33. Sumida, K.; Rogow, D.L.; Mason, J.A.; McDonald, T.M.; Bloch, E.D.; Herm, Z.R.; Bae, T.-H.; Long, J.R. Carbon dioxide capture in metal-organic frameworks. Chem. Rev. 2012, 112, 724-781. [CrossRef] [PubMed]

34. Yoon, M.; Srirambalaji, R.; Kim, K. Homochiral metal-organic frameworks for asymmetric heterogeneous catalysis. Chem. Rev. 2012, 112, 1196-1231. [CrossRef] [PubMed]

35. Liu, J.; Chen, L.; Cui, H.; Zhang, J.; Zhang, L.; Su, C.-Y. Applications of metal-organic frameworks in heterogeneous supramolecular catalysis. Chem. Soc. Rev. 2014, 43, 6011-6061. [CrossRef] [PubMed]

36. Kreno, L.E.; Leong, K.; Farha, O.K.; Allendorf, M.; Van Duyne, R.P.; Hupp, J.T. Metal-organic framework materials as chemical sensors. Chem. Rev. 2012, 112, 1105-1125. [CrossRef] [PubMed]

37. Hu, Z.; Deibert, B.K.; Li, J. Luminescent metal-organic frameworks for chemical sensing and explosive detection. Chem. Soc. Rev. 2014, 43, 5815-5840. [CrossRef]

38. Horcajada, P.; Gref, R.; Baati, T.; Allan, P.K.; Maurin, G.; Couvreur, P.; Férey, G.; Morris, R.E.; Serre, C. Metal-organic frameworks in biomedicine. Chem. Rev. 2012, 112, 1232-1268. [CrossRef]

39. Wang, L.; Zheng, M.; Xie, Z. Nanoscale metal-organic frameworks for drug delivery: A conventional platform with new promise. J. Mater. Chem. B 2018, 6, 707-717. [CrossRef]

40. Xu, M.; Yuan, S.; Chen, X.-Y.; Chang, Y.-J.; Day, G.; Gu, Z.-Y.; Zhou, H.-C. Two-dimensional metal-organic framework nanosheets as an enzyme inhibitor: Modulation of the $\alpha$-Chymotrypsin activity. J. Am. Chem. Soc. 2017, 139, 8312-8319. [CrossRef]

41. Sun, H.; Tang, B.; Wu, P. Rational design of S-UiO-66@GO hybrid nanosheets for proton exchange membranes with significantly enhanced transport performance. ACS Appl. Mater. Interfaces 2017, 9, 26077-26087. [CrossRef] [PubMed]

42. Li, Z.; He, G.; Zhao, Y.; Cao, Y.; Wu, H.; Li, Y.; Jiang, Z. Enhanced proton conductivity of proton exchange membranes by incorporating sulfonated metal-organic frameworks. J. Power Sources 2014, 262, 372-379. [CrossRef]

43. Zhang, B.; Cao, Y.; Li, Z.; Wu, H.; Yin, Y.; Cao, L.; He, X.; Jiang, Z. Proton exchange nanohybrid membranes with high phosphotungstic acid loading within metal-organic frameworks for PEMFC applications. Electrochim. Acta 2017, 240, 186-194. [CrossRef]

44. Park, K.S.; Ni, Z.; Cote, A.P.; Choi, J.Y.; Huang, R.; Uribe-Romo, F.J.; Chae, H.K.; O'Keeffe, M.; Yaghi, O.M. Exceptional chemical and thermal stability of zeolitic imidazolate frameworks. Proc. Natl. Acad. Sci. USA 2006, 103, 10186-10191. [CrossRef] [PubMed]

45. Phan, A.; Doonan, C.J.; Uribe-Romo, F.J.; Knobler, C.B.; O'Keeffe, M.; Yagh, O.M. Synthesis, structure, and carbon dioxide capture properties of zeolitic imidazolate frameworks. Acc. Chem. Res. 2010, 43, 58-67. [CrossRef] [PubMed]

46. Sun, H.; Tang, B.; Wu, P. Two-Dimensional zeolitic imidazolate framework/carbon nanotube hybrid networks modified proton exchange membranes for improving transport properties. ACS Appl. Mater. Interfaces 2017, 9, 35075-35085. [CrossRef] [PubMed]

47. McCarthy, M.C.; Varela-Guerrero, V.; Barnett, G.V.; Jeong, H.-K. Synthesis of zeolitic imidazolate framework films and membranes with controlled microstructures. Langmuir 2010, 26, 14636-14641. [CrossRef]

48. Qian, J.; Sun, F.; Qin, L. Hydrothermal synthesis of zeolitic imidazolate framework-67 (ZIF-67) nanocrystals. Mater. Lett. 2012, 82, 220-223. [CrossRef] 
49. Wu, B.; Pan, J.F.; Ge, L.; Wu, L.; Wang, H.T.; Xu, T.W. Oriented MOF-polymer composite nanofiber membranes for high proton conductivity at high temperature and anhydrous condition. Sci. Rep. 2014, 4, 4334. [CrossRef]

50. Panchariya, D.K.; Rai, R.K.; Kumar, E.A.; Singh, S.K. Core-shell zeolitic imidazolate frameworks for enhanced hydrogen storage. ACS Omega 2018, 3, 167-175. [CrossRef]

51. Rangel-Cárdenas, A.L.; Koper, G.J.M. Transport in Proton Exchange Membranes for Fuel Cell Applications-A Systematic Non-Equilibrium Approach. Materials 2017, 10, 576. [CrossRef]

52. Escorihuela, J.; Sahuquillo, O.; García-Bernabé, A.; Giménez, E.; Compañ, V. phosphoric acid doped polybenzimidazole (PBI) / zeolitic imidazolate framework composite membranes with significantly enhanced proton conductivity under low humidity conditions. Nanomaterials 2018, 8, 775. [CrossRef] [PubMed]

53. Wu, H.; Shen, X.H.; Cao, Y.; Li, Z.; Jiang, Z.Y. Composite proton conductive membranes composed of sulfonated poly(ether ether ketone) and phosphotungstic acid-loaded imidazole microcapsules as acid reservoirs. J. Membr. Sci. 2014, 451, 74-84. [CrossRef]

54. Nie, L.L.; Wang, J.T.; Xu, T.; Dong, H.; Wu, H.; Jiang, Z.Y. Enhancing proton conduction under low humidity by incorporating core-shell polymeric phosphonic acid submicrospheres into sulfonated poly(ether ether ketone) membrane. J. Power Sources 2012, 213, 1-9. [CrossRef]

55. Xing, P.; Robertson, G.P.; Guiver, M.D.; Mikhailenko, S.D.; Wang, K.; Kaliaguine, S. Synthesis and characterization of sulfonated poly(ether ether ketone) for proton exchange membranes. J. Membr. Sci. 2004, 229, 95-106. [CrossRef]

56. Ru, C.; Li, Z.; Zhao, C.; Duan, Y.; Zhuang, Z.; Bu, F.; Na, H. Enhanced proton conductivity of sulfonated hybrid poly(aryleneether ketone) membranes by incorporating an amino-sulfobifunctionalized metal-organic framework for direct methanol fuel cells. ACS Appl. Mater. Interfaces 2018, 10, 7963-7973. [CrossRef]

57. Lee, C.H.; Park, H.B.; Lee, Y.M.; Lee, R.D. Importance of proton conductivity measurement in polymer electrolyte membrane for fuel cell application. Ind. Eng. Chem. Res. 2005, 44, 7617-7626. [CrossRef]

58. Lânyi, Š. Polarization in ionic crystals with incompletely blocking electrodes. J. Phys. Chem. Solids 1975, 36, 775-781. [CrossRef]

59. Ogihara, N.; Itou, Y.; Sasaki, T.; Takeuchi, Y. Impedance spectroscopy characterization of porous electrodes under different electrode thickness using a symmetric cell for high-performance lithium-ion batteries. J. Phys. Chem. C 2015, 119, 4612-4619. [CrossRef]

60. Vega, J.; Andrio, A.; Lemus, A.A.; del Castillo, L.F.; Compañ, V. Conductivity study of zeolitic imidazolate frameworks, tetrabutylammonium hydroxide doped with zeolitic imidazolate frameworks, and mixed matrix membranes of polyetherimide/tetrabutylammonium hydroxide doped with zeolitic imidazolate frameworks for proton conducting applications. Electrochim. Acta 2017, 258, 153-166.

61. Zhang, J.; Bai, H.-J.; Ren, Q.; Luo, H.-B.; Ren, X.-M.; Tian, Z.-F.; Lu, S. Extra water- and acid-stable MOF-801 with high proton conductivity and its composite membrane for proton-exchange membrane. ACS Appl. Mater. Interfaces 2018, 10, 28656-28663. [CrossRef] [PubMed]

62. Zheng, Y.; Zheng, S.; Xue, H.; Pang, H. Metal-organic frameworks/graphene-based materials: Preparations and applications. Adv. Funct. Mater. 2018, 28, 1804950. [CrossRef]

63. Lux, F.J. Models proposed to explain the electrical conductivity of mixtures made of conductive and insulating materials. Mater. Sci. 1993, 28, 285-301. [CrossRef]

64. Nan, C.W.; Smith, D.M. Ac electrical properties of composite solid electrolytes. Mater. Sci. Eng. B 1991, 10, 99-106. [CrossRef]

65. Wang, Y.; Sun, C.N.; Fan, F.; Sangoro, J.R.; Berman, M.B.; Greenbaum, S.G.; Zawodzinski, T.A.; Sokolov, A.P. Examination of methods to determine free-ion diffusivity and number density from analysis of electrode polarization. Phys. Rev. E 2013, 87, 042308. [CrossRef] [PubMed]

66. Klein, R.J.; Zhang, S.; Dou, S.; Jones, B.H.; Colby, R.H.; Runt, J. Modeling electrode polarization in dielectric spectroscopy: Ion mobility and mobile ion concentration of single-ion polymer electrolytes. J. Chem. Phys. 2006, 124, 144903. [CrossRef] [PubMed] 
67. MacDonald, J.R. Theory of AC space-charge polarization effects in photoconductors, semiconductors, and electrolytes. Phys. Rev. 1953, 92, 4-17. [CrossRef]

68. Sørensen, T.S.; Compañ, V.; Diaz-Calleja, R. Complex permittivity of a film of poly [4-(acryloxy)phenyl-(4chlorophenyl)methanone] containing free ion impurities and the separation of the contributions from interfacial polarization, Maxwell-Wagner-Sillars effects and dielectric relaxations of the polymer chains. J. Chem. Soc. Faraday Trans. 1996, 92, 1947-1957.

69. Sørensen, T.S.; Compañ, V. Complex permittivity of a conducting, dielectric layer containing arbitrary binary Nernst-Planck electrolytes with applications to polymer films and cellulose acetate membranes. J. Chem. Soc. Faraday Trans. 1995, 91, 4235-4250. [CrossRef]

70. Serghei, A.; Tress, M.; Sangoro, J.R.; Kremer, F. Electrode polarization and charge transport at solid interfaces. Phys. Rev. 2009, 80, 184301. [CrossRef]

71. Bandara, T.M.W.J.; Dissanayake, M.A.K.L.; Albinsson, I.; Mellander, B.-E. Mobile charge carrier concentration and mobility of a polymer electrolyte containing PEO and $\operatorname{Pr}_{4} \mathrm{~N}^{+} \mathrm{I}^{-}$using electrical and dielectric measurements. Solid State Ionics 2011, 189, 63-68. [CrossRef]

72. Coelho, R. Sur la relaxation d'une charge d'espace. Revue Phys. Appl. 1983, 18, 137. [CrossRef]

73. Schütt, H.J.; Gerdes, E. Space-charge relaxation in ionicly conducting oxide glasses. I. Model and frequency response. J. Non-Cryst. Solids 1992, 144, 1-13. [CrossRef]

74. Altava, B.; Compañ, V.; Andrio, A.; del Castillo, L.F.; Mollá, S.; Burguete, M.I.; García-Verdugo, E.; Luis, S.V. Conductive films based on composite polymers containing ionic liquids absorbed on crosslinked polymeric ionic-like liquids (SILLPs). Polymer 2015, 72, 69-81. [CrossRef]

75. García-Bernabé, A.; Rivera, A.; Granados, A.; Luis, S.V.; Compañ, V. Ionic transport on composite polymers containing covalently attached and absorbed ionic liquid fragments. Electrochim. Acta 2016, 213, 887-897. [CrossRef]

76. Cole, K.S.; Cole, R.H. Dispersion and Absorption in Dielectrics I. Alternating Current Characteristics. J. Chem. Phys. 1941, 9, 341-351.

77. Sangoro, J.R.; Iacob, C.; Agapov, A.L.; Wang, Y.; Berdzinski, S.; Rexhausen, H.; Strehmel, V.; Friedrich, C.; Sokolov, A.P.; Kremer, P. Decoupling of ionic conductivity from structural dynamics in polymerized ionic liquids. Soft Matter 2014, 10, 3536-3540. [CrossRef] [PubMed]

78. Krause, C.; Sangoro, J.R.; Iacob, C.; Kremer, F. Charge transport and dipolar relaxations in imidazolium-based ionic liquids. J. Phys. Chem. B 2010, 114, 382-386. [CrossRef] 